\title{
Follow-up care of children with vertebral body compression fractures (evidence from Saint Petersburg)
}

\author{
A.G. Baindurashvili, A.V. Zaletina, S.V. Vissarionov, K.S. Solovyova
}

The Turner Scientific and Research Institute for Children's Orthopedics, Saint Petersburg, Russian Federation

\begin{abstract}
Introduction The incidence of compression spine injuries account for $0.49 \%$ to $0.9 \%$ of total pediatric trauma victims. Spine fractures constitute $7.5 \%$ to $14.6 \%$ of all inpatient hospital admissions and require conservative treatment. The aim of the study is to analyze the system of outpatient rehabilitation of pediatric compression vertebral fractures at follow-up care provided in St. Petersburg. Material and methods Medical records of 1230 children and adolescents who sustained compression fractures of the vertebral bodies and were followed up by orthopaedic surgeons in St. Petersburg between 2011 and 2017 have been reviewed. Results and discussion Pediatric bone fractures constituted $24.8 \%$ of total injuries registered in St. Petersburg in 2017. From pediatric vertebral body victims, $53 \%$ were boys and $47 \%$ were girls. Vertebral fractures were most common in children aged nine, ten and eleven years (range, 13\% - $14 \%$ ). A system of consistent non-operative treatment performed for the patients at trauma departments of children's hospitals, through inpatient and outpatient services of rehabilitation and restorative treatments, follow-up care in the outpatient setting is presented. Conclusion The incidence of pediatric bone injury and vertebral body compression fractures is higher in St. Petersburg than the average incidence reported in the Russian Federation. Questions of overdiagnosis of vertebral body compression fractures in pediatric population are considered to be important and relevant. An overview of treatment options and strategies, utilization of braces, follow-up term required for children with compression vertebral body fractures suggests revised approaches to treatment methods, length of inpatient management and follow-up care.
\end{abstract}

Keywords: vertebral compression fracture, conservative treatment, follow-up care, children

\section{INTRODUCTION}

Skeletal pediatric fractures from external causes registered in the Russian Federation in 2016 constituted $21.6 \%$ of all musculoskeletal injuries in children from birth to 17 years of age. The mean annual incidence was 24.7 per 1000 children. Pediatric spine fractures constituted $0.9 \%$ of all pediatric fractures with the mean annual incidence of 1.1 per 1000 children [1]. Absolute number of pediatric fractures of specific vertebrae could not be identified with governmental statistical resources since fractures of thoracic vertebra are coded together with fractures of ribs and fractures of sternum (0.7 \%) in S22 section of ICD-10 and fractures of lumbar vertebra and sacrum are coded together with pelvic injuries (0.2 \%) in S32 section. E.G. Skryabin et al. (2013) reported a 2-year study of pediatric injuries in the city of Tyumen that detected that compression spine injuries accounted for $0.49 \%$ of total pediatric trauma victims [2]. Different incidence rate of pediatric spine injuries was reported in 55 regions of the Russian Federation. There were $10.34 \pm 11.55$ cases of superficial spine injuries, $4.30 \pm 3.90$ compression spine fractures and $0.20 \pm 0.20$ unstable and complicated vertebral fractures reported per 10000 children [3]. Spine fractures constituted $7.5 \%$ to $14.6 \%$ of all inpatient hospital admissions [4].

Pediatric compression spine fractures have specific characteristics. Fractures of one or several vertebrae can result from minor trauma causing mild, short term pain and nonspecific clinical symptoms. For these reasons, the diagnosis of compression spine fractures in children is frequently delayed and can lead to complications [5, 6, 7]. Pediatric compression spine fractures can be treated conservatively. Functional method has been used for many years and recongnized by most orthopaedic and trauma surgeons. A child with vertebral compression fracture would be treated as an inpatient staying in bed on a firm mattress for 3-4 weeks with head of bed elevated for functional spine traction combined with gradually complexified physical exercises using technique developed by V.V. Gorinevsky and E.F. Dreving for strengthening the back and abdominal muscles. There is a paucity of literature exploring two-year follow-up of rehabilitation after fracture when a child is followed

@aindurashvili A.G., Zaletina A.V., Vissarionov S.V., Solovyova K.S. Follow-up care of children with vertebral body compression fractures (evidence from Saint Petersburg). Genij Ortopedii, 2019, vol. 25, no 4, pp. 535-540. DOI 10.18019/1028-4427-2019-254-535-540. (In Russian) 
up by an orthopaedic surgeon in the outpatient setting. The use of rehabilitation therapies at home may be difficult because of the child's age. Children may have difficulties in adhering to the restrictions of treatment regimen of sitting regulations, exercise therapy program and use of bracing. Children need more help and support from the family that might be a problem. The literature convincingly demonstrates that pediatric compression vertebral fractures can lead to substantial morbidity and managment strategies are equally important in acute period and during rehabilitation [7-12].

The aim of the study was to analyze the system of outpatient rehabilitation of pediatric compression vertebral fractures at follow-up care provided in St. Petersburg. The goals of the research were to analyze epidemiological characteristics of the patients including gender, age, incidence of spine injuries at different levels, number of involved vertebrae, length of inpatient stay at a trauma unit of the 'Ogonyek' municipal restorative children's center for trauma and orthopaedics and other rehabilitation institutions. Volume of care rendered to children with compression vertebral fractures with focus on complex restorative treatment provided by regional orthopaedic surgeon in the outpatient settings was evaluated with use of data from outpatient services of St. Petersburg.

\section{MATERIAL AND METHODS}

National statistical data on musculoskeletal conditions, injuries and medical services rendered to the children of Russia because of such conditions were used in the study [1]. St.Petersburg National Statistical Form № 57 „Data on trauma, toxic exposures and other consequences from external causes. Trauma by pattern and external causes in children from birth to 17 years inclusive - S00-T98“. Standard form „Operational performance of healthcare facilities Profile trauma pediatric beds" [13]. Data on followup care and restorative management of 1230 patients with compression vertebral fractures treated between 2011 and 2017 were provided by pediatric orthopaedic surgeons from 37 outpatient clinics of St.Petersburg.

\section{RESULTS AND DISCUSSION}

Pediatric bone fractures from external causes constituted $24.8 \%$ of total injuries registered in St. Petersburg in 2017 according to National Statistical Form № 57 . Fractures of the cervical spine constituted $0.16 \%$, of the thoracic spine, ribs and sternum $4.9 \%$ and injuries to the lumbar spine and pelvic bones accounted for $1.3 \%$ of the total pediatric fractures seen in St.Petersburg in 2017 [14]. The incidence of pediatric bone injury was shown to be higher in St. Petersburg than the average incidence reported in the Russian Federation. Fractures of the cervical spine constituted $0.04 \%$, injuries to the thoracic spine, ribs and sternum, $1.22 \%$ and injuries to the lumbar spine and pelvic bones accounted for $1.22 \%$ of the total pediatric fractures registered in the Russian Federation [1, 14] (Table 1). This could be ascribed to a high rate of urbanization in St.Petersburg, general pediatric health condition, low solar exposure, cold and humid weather as compared to other regions of the country.
Medical records of 1230 children with spine fractures were reviewed. From pediatric vertebral body victims, $53 \%$ were boys and $47 \%$ were girls. Vertebral fractures were most common in children aged nine, ten and eleven years (range, $13 \%-14 \%$ ) due to their physical activities and sports. Next groups by incidence of injured vertebrae included children aged eight and twelve years (11 \% for each), then six, seven and thirteen years (from 6.2 to $7.8 \%$ ). $4 \%$ of detected fractures fell on children aged five and fourteen years, and $2 \%$ and less fell on kids younger than three and older than sixteen years (Table 2).

Table 3 shows frequency of specific localization of compression vertebral fracture. If there were several fractures occurred in two adjacent vertebrae localization was recorded at the level of greater number of injuries. The review showed that $93.5 \%$ of injuries were localized in thoracic spine with Th58 level (apex of physiological kyphosis) involved in $52.3 \%$ of the cases. 
Table 1

Incidence of pediatric skeletal injury registered in Russia and St.Petersburg in 2017

\begin{tabular}{|l|c|c|}
\hline \multicolumn{1}{|c|}{ Description } & Russia & St.Petersburg \\
\hline Incidence of injury per 1 000 children from birth to 14 years & 105.2 & 142.1 \\
\hline Incidence of injury per 1 000 children from 15 to 17 years & 174.6 & 267.7 \\
\hline Prevalence of bone injury in children from birth to 17 years & $21.6 \%$ & $24.8 \%$ \\
\hline Prevalence of compression vertebral fractures: & $0 \%$ & $0.04 \%$ \\
\hline cervical spine injury & $0.7 \%$ & $1.22 \%$ \\
\hline fractures of ribs, sternum and thoracic spine & 0.2 & $0.33 \%$ \\
\hline fractures of lumbosacral spine and pelvic bones
\end{tabular}

Table 2

Distribution of patients with vertebral body fractures by age

\begin{tabular}{|l|c|c|c|c|c|c|c|c|c|c|c|c|c|c|c|}
\hline $\begin{array}{l}\text { Age (years, at } \\
\text { last birthday ) }\end{array}$ & $\leqslant 3$ & 4 & 5 & 6 & 7 & 8 & 9 & 10 & 11 & 12 & 13 & 14 & 15 & 16 & $\geqslant 17$ \\
\hline \% victims & 0.8 & 2.2 & 4.0 & 6.2 & 7.8 & 11.0 & 13.3 & 14.1 & 13.0 & 10.9 & 7.0 & 3.7 & 2.7 & 2.2 & 1.1 \\
\hline
\end{tabular}

Table 3

Localization of vertebral compression fractures

\begin{tabular}{|l|c|}
\hline Sections of vertebral column & $\%$ \\
\hline Cervical & $\geqslant 1.0$ \\
\hline Upper thoracic (Th1-4) & 17.9 \\
\hline Medium thoracic (Th 5-8) & 52.3 \\
\hline Low thoracic (Th 9-12) & 23.3 \\
\hline Thoracolumbar & 1.8 \\
\hline Lumbar & 3.7 \\
\hline
\end{tabular}

Isolated compression fracture of one vertebra was observed in $32.7 \%$ of all cases and $67.3 \%$ of children had injuries to two and more vertebrae. Compression of two vertebrae was observed in $29.7 \%$ of the patients, three vertebrae, in $22.3 \%$ and four vertebrae, in $9.4 \%$ of the patients. Compression of five $(4.5 \%)$ and more $(1.4 \%)$ vertebrae were seen in several cases. Our research relied on the diagnosis made by specialists at municipal hospitals and it was not our aim to identify whether there was overdiagnosis or not. It should be noted that unstable and complicated spine injuries to be repaired surgically were distributed in a different manner. Review of spine injuries between 2000 and 2017 showed that lumbar spine fractures were most common to be followed by thoracolumbar injuries, and then, thoracic spine fractures. This distribution of spine fracture localization can be explained by several factors. First, thoracic spine is the most stable section as compared to other spinal motion segments. Second, the sternum plays an important adjunctive stabilizing function in the thoracic region of the axial skeleton and with the ribs, represents an additional column of stability. Considering the difference in the incidence of stable and unstable spine fractures with regard to localization, overdiagnosis of compression vertebral fractures is unlikely to be ruled out.
Epidemiological characteristics (gender, age) of St.Petersburg's patients and localization of vertebral fractures reviewed in a great number of cases $(n=1230)$ were found, for the most part, to be identical to those reported in a 2-year series of compression fractures $(n=199)$ performed in the city of Tyumen [2].

Vertebrae were detected to be intact between broken vertebrae in $14.3 \%$ of patients. One intact vertebra between two injured ones was observed in $9.2 \%$. Multiple fractures of vertebral bodies is one of specific features of spine injuries in childhood. Thoracic vertebrae $9,6,8,4$ and 10 (with decline) were commonly intact in the group of patients. Sometimes there were two intact vertebrae between the groups of broken vertebrae. These vertebrae were close to each other in $3.4 \%$. Combinations of Th4 and 5, Th5 and 6, Th6 and 7, Th7 and 8 vertebrae were most common, and Th9 and 10 vertebrae were rare. Two intact vertebrae were located at a distance to each other in $1.7 \%$. Combinations of Th7 and Th9, Th6 and Th8 were most common.

All children with vertebral fractures were admitted as casulaties to specialized trauma units of St. Petersburg municipal children's hospitals № 1 , № 2 St. Mary Magdalene, № 5 named after N.F. Filatov, № 19 named after K.A. Rauchfuß, № 22 and to the 
hospital of St. Petersburg State Pediatric Medical University. Based on physical and radiological examinations added by magnetic resonance imaging diagnosis was made and pain management produced. It was very important to diagnose and identify unstable and complicated pediatric spine fractures [15-17]. Nine patients showed unstable vertebral body fractures and complicated injuries with neurological deficiency of different severity and were seen by consultants from the Turner Scientific and Research Institute for Children's Orthopedics Minzdrava Rossii. The victims were either referred to the Turner Hospital or underwent surgical reduction and fixation of the spinal motion segment with metal constructs and decompression of the spinal cord within the first hours of injury at the hospital of admission.

Classical conservative treatment of compression vertebral fractures of inpatients included bed rest on a firm mattress with head of the bed elevated during the first month after injury $[8,9]$. The broken spinal fragment was unloaded by traction on the oblique plane using axillary vault or Glisson loop and the patient's weight. Depending on localization and number of injured vertebrae the patient underwent physiotherapeutic procedures, stimulating massage and a set of gradually complexified physical exercises lying on the back and abdomen applied with technique developed by V.V. Gorinevsky and E.F. Dreving for strengthening the back and abdominal muscles. The length of inpatient admission was different ranging from several days to two months and could not be explained by fracture localization and number of broken vertebrae. Some parents refused hospitalization and long term treatment at the hospital so that pediatric inpatients stayed at the hospital for a few days. Bed/day of vertebral fractures treated at the above hospitals ranged from $271 / 2$ to 36 days.

Patients with compression vertebral fractures treated at St.Petersburg could receive rehabilitation treatment at the hospitals of other cities after they got discharged from trauma departments. $68.2 \%$ of the study group of patients with compression vertebral fractures received treatment at the 'Ogonyek' Restorative children's center for trauma and orthopaedics and $5.6 \%$ from them were readmitted. A complex restorative treatment lasted from 5 to 7 weeks. Patients continued bed rest at the 'Ogonyek' center to receive more complete vertebral unloading. The length of bed rest was determined by localization and number of injured vertebrae. Patients continued with the physiotherapeutic procedures, body massage, physical exercises in accordance with periods III and IV of the technique of V.V. Gorinevsky and
E.F. Dreving. Patients were psychologically adapted to restrict loading, extend ambulation regime and daily living activities [18].

$17 \%$ of patients with compression vertebral fractures were discharged from trauma departments of municipal hospitals and continued restorative treatment (exercise therapy, massage, electrophoresis, magnet therapy) at other hospitals including pediatric department of hospital № 40 (4.6\%), rehabilitation department of hospital № 22 (8.7 \%) and other hospitals in Russia (3.7 \%). Parents of $2.9 \%$ of patients refused inpatient restorative treatment and $11.9 \%$ of children received no rehabilitation at the hospitals for unknown reason. Pediatric orthopadic and trauma surgeons provided follow-up care for patients with compression vertebral fractures at pediatric outpatient facilities. Follow-up care started 1 to 3 months after injury when patients were discharged from a trauma department at a hospital or after rehabilitation at a specialized clinic and lasted for two years. Follow-up care included physical examination, discussion with parents providing recommendations of therapeutic and protective regimen, reclination corset, referral to courses of exercise therapy, massage, physiotherapy restricting participation in sports activities. Exercise therapy plays a critical role in the rehabilitation of patients with compression vertebral fractures using extension or isometric back and abdominal strengthening exercises that are consistent with periods III and IV of the technique devised by E.F. Dreving and V.V. Gorinevsky. Every other phase involved more complicated maneuvers.

An orthopaedic surgeon evaluated patient's characteristics depending on the time after injury and localization of fracture and provided specific recommendations on vertical loading and rest regime throughout the day, home-based exercise program at an ambulatory follow-up visit. The child was not allowed to sit, was advised to do homeschool classes and read while lying down up to 4-month follow-up. After 4 months the patient was allowed to sit for the recommended period of time gradually increasing the time with appropriate radiological signs and absence of negative dynamics. Patient could return to school after 6 months with limited classes attendance.

Pain was recorded in outpatient charts of $22.2 \%$ of patients. From them, $17.6 \%$ reported pain in the thoracic spine or low back in the first two months after injury, $2.7 \%$ in the first 3-4 months, $1.5 \%$ during 5-6 months and $0.4 \%$ had intermittent pain at one-year follow-up. Continuous use of orthoses recommended by orthopaedists after compression vertebral fracture ranged from one month to two years and depended on 
the number and localization of broken vertebrae. Use of orthoses was 1 month in $2.5 \%, 2$ months in $4.8 \%$, 3 months in $7 \%, 4$ months in $16.8 \%, 6$ to 8 months in $23 \%, 1$ year in $23.6 \%$ and 2 years in $11 \%$ of patients. No orthoses use duration was recorded in $5.7 \%$ of patients and $4.4 \%$ were recommended but did not use it. Recommendations of using orthoses for 2 years were given by one specialist from 26 outpatient clinics and were likely to be exaggerated. The mean period of orthoses use is meant to range between six months and one year to invoke corset's disciplinary function and facilitate sitting and standing postural balance. In addition to the home exercises patients could have regular outpatient clinic sessions (clinicbased rehabilitation). Supervised group exercise classes were arranged for $83.2 \%$ at outpatient clinic twice each year of observation. The course of exercises was administered for $14.4 \%$ of children once the first year of observation. Parents were asked to supervise in-treatment adherense to home-based exercise therapy but no findings were available as to the quality of the rehabilitation. $2.4 \%$ of children were on home-based rehabilitation program only skipping supervised group exercise classes.

$95.4 \%$ of children received 10 sessions of massage therapy during ambulatory follow-up care once a year (20.9 \%) and twice a year (74.5\%). $4.6 \%$ of children received no massage therapy for unknown reasons. Physiotherapeutic procedures included applications of ultraviolet irradiation, ultrahigh frequency, electrophoresis with novokain, calcium, aminophilline, magnet tharapy, electric stimulation of vertebral muscles and paraffin depending on the time after injury. Restictions in sporting activities, jumping, neck springs, weight lifting were recommended to all patients within two years after injury. Rest was also advised throughout the day. None of the patients who sustained compression vertebral fractures and were treated conservatively was referred to be inspected by disability board of review. Children appeared to be healthy after two-year follow-up care with the ambulatory program successfully accomplished.

\section{CONCLUSION}

1. The incidence of pediatric bone injury and vertebral body compression fractures is higher in St. Petersburg than the average incidence reported in the Russian Federation.

2. Compression vertebral fractures are equally encountered in girls and boys with mild overbalance in the latter.

3. Compression thoracic spine fractures are most common and used to occur at the age of 9-12 years. Less incidence of vertebral body fractures is noted in children younger than 3 years and older than 16 years.
4. Pain was shown to persist in $0.4-22.2 \%$ of pediatric compression spine fractures throughout the whole follow-up care period despite long term inpatient treatment followed by restorative rehabilitaton.

5. Questions of overdiagnosis of vertebral body compression fractures in pediatric population are considered to be important and relevant.

6. A thorough study of the treatment volume and strategy, orthotic design options, duration of follow-up care of children with compression vertebral body fractures would necessitate revised approaches to therapeutic techniques, duration of inpatient stay and ambulatory follow-up.

Conflict of interests and funding The authors declare that there is no conflict of interests regarding the publications of this article.

The research was supported by the Turner Scientific and Research Institute for Children's Orthopedics Minzdrava Rossii.

Acknowledgements The authors would like to thank orthopaedic and trauma surgeons of St.Petersburg who provided data on ambulatory follow-up care of children with compression vertebral body fractures.

\section{REFERENCES}

1. Mironov S.P. Travmatizm, ortopedicheskaia zabolevaemost, sostoianie travmatologo-ortopedicheskoi pomoshchi naseleniiu Rossii v 2016 godu: sbornik [Traumatism, Orthopedic Morbidity, the State of Traumatologic and Orthopedic Care to Russia Population in 2016: Collection of Works]. M., 2017, 149 p. (in Russian)

2. Skriabin E.G., Sergeev K.S., Smirnykh A.G. Kompressionnye neoslozhnennye perelomy tel pozvonkov: rezultaty ezhednevnogo monitoring situatsii za dva goda na primere149-tysiachnogo detskogo naseleniia goroda Tiumeni [Compression uncomplicated fractures of vertebral bodies: results of the situation daily monitoring over two years by the example of 149,000-child population of Tiumen]. Genij Ortopedii, 2013, no. 3, pp. 48-51. (in Russian)

3. Zaletina A.V., Vissarionov S.V., Baindurashvili A.G., Sadovoi M.A., Soloveva K.S., Kuptsova O.A. Struktura povrezhdenii pozvonochnika u detei v regionakh Rossiiskoi Federatsii [Structure of the spine injuries in children in the regions of the Russian Federation]. Khirurgiia Pozvonochnika, 2017, vol. 14, no. 4, pp. 52-60. (in Russian) DOI: 10.14531/ss2017.4.52-60. 
4. Vishniakov A.N., Drozhzhina L.A., Vishniakov N.I. Sostoianie i nekotorye problem reabilitatsii detei (0-17 let) s travmami kostnomyshechnoi sistemy posle spetsializirovannogo statsionarnogo lecheniia [Condition and some problems of rehabilitation of children (0-17 years old) with injuries of the osteomuscular system after specialized in-patient treatment]. Vestnik Vserossiiskogo Obshchestva Spetsialistov po Mediko-Sotsialnoi Ekspertize, Reabilitatsii i Reabilitatsionnoi Industrii, 2016, no. 1, pp. 25-31. (in Russian)

5. Angelliaume A., Bouty A., Sales De Gauzy J., Vital J.M., Gille O., Boissière L., Tournier C., Aunoble S., Pontailler J.R., Lefèvre Y. Post-trauma scoliosis after conservative treatment of thoracolumbar spinal fracture in children and adolescents: results in 48 patients. Eur. Spine J., 2016, vol. 25, no. 4, pp. 1144-1152. DOI: 10.1007/s00586-014-3744-6.

6. Singer G., Parzer S., Castellani C., Wegmann H., Lindbichler F., Till H., Eberl R. The influence of brace immobilization on the remodeling potential of thoracolumbar impaction fractures in children and adolescents. Eur. Spine J., 2016, vol. 25, no. 2, pp. 607613. DOI: 10.1007/s00586-015-4250-1.

7. Baindurashvili A.G., Vissarionov S.V., Pavlov I.V., Kokushin D.N., Lein G.A. Konservativnoe lechenie detei s kompressionnymi perelomami pozvonkov grudnoi i poiasnichnoi lokalizatsii v Rossiiskoi Federatsii (obzor literatury) [Conservative treatment of children with compression fractures of the thoracic and lumbar vertebrae in the Russian Federation (review of the literature)]. Ortopediia, Travmatologiia i Vosstanovitelnaia Khirurgiia Detskogo Vozrasta, 2016, vol. 4, no. 1, pp. 48-56. (in Russian) DOI: 10.17816/PTORS4148-56.

8. Epifanov V.A., Epifanov A.V. Vosstanovitelnoe lechenie pri zabolevaniiakh i povrezhdeniiakh pozvonochnika [Rehabilitation treatment for diseases and injuries of the spine]. M., MEDpress-inform, 2008, 383 p. (in Russian)

9. Astakhova N.A., Zhila N.G. Konservativnoe lechenie kompressionnykh perelomov pozvonochnika u detei [Conservative treatment of compression fractures of the spine in children]. Dalnevostochnyi Meditsinskii Zhurnal, 2012, no. 1, pp.127-130. (in Russian)

10.Astakhova N.A., Zhila N.G. Ispolzovanie rekliniruiushchikh ustroistv v protsesse dispansernogo nabliudeniia detei $\mathrm{s}$ kompressionnymi perelomami pozvonochnika [Using retractor devices in the process of care-associated observation of children with compression fractures of the spine]. Dalnevostochnyi Meditsinskii Zhurnal, 2013, no. 1, pp. 39-41. (in Russian)

11.Skriabin E.G., Smirnykh A.G. Giperdiagnostika kompressionnykh neoslozhnennykh perelomov tel pozvonkov u detei [Hyperdiagnosis of compression uncomplicated fractures of vertebral bodies in children]. Sovremennye Problemy Nauki i Obrazovaniia, 2017, no. 2, pp. 123-130. (in Russian)

12.Angelliaume A., Simon A.L., Boissière L., Bouty A., Sales de Gauzy J., Vital J.M., Gille O., Tournier C., Aunoble S., Pontailler J.R., Lefèvre Y. Conservative treatment of pediatric thoracic and lumbar spinal fractures: outcomes in the sagittal plane. J. Pediatr. Orthop. B, 2017, vol. 26, no. 1, pp. 73-79. DOI: 10.1097/BPB.0000000000000329.

13.Statisticheskie dannye (Forma 57 «Travmy po Kharakteru i Sootvetstvuiushchie im Vneshnie Prichiny u Detei» i Forma 19 «Detskaia Invalidnost») [Statistical Form 57 "Injuries by the Character and the Corresponding External Causes in Children”, and Statistical Form 19 “Children's Disability”]. SPb. SBHI “MIATs”, 2017. (in Russian)

14.Soloveva K.S., Zaletina A.V. Travmatizm detskogo naseleniia Sankt-Peterburga [Injuries of St. Petersburg children's population]. Ortopediia, Travmatologiia i Vosstanovitelnaia Khirurgiia Detskogo Vozrasta, 2017, vol. 5, no. 3, pp. 43-49. (in Russian) DOI: 10.17816/PTORS5343-49.

15.Merkulov V.N., Rodionova S.S., Ilina V.K., Zhigacheva A.V., Lapkina S.V. Povrezhdeniia grudnogo i poiasnichnogo otdelov pozvonochnika na fone iuvenilnogo osteoporoza [Injuries of the thoracic and lumbar spine through juvenile osteoporosis]. Vestnik Travmatologii i Ortopedii im. N.N. Priorova, 2002, no. 1, pp. 7-11. (in Russian)

16.Rush J.K., Kelly D.M., Astur N., Creek A., Dawkins R., Younas S., Warner W.C. Jr., Sawyer J.R. Associated injuries in children and adolescents with spinal trauma. J. Pediatr. Orthop., 2013, vol. 33, no. 4, pp. 393-397. DOI: 10.1097/BPO.0b013e318279c7cb.

17.Arkader A., Warner W.C. Jr., Tolo V.T., Sponseller P.D., Skaggs D.L. Pediatric Chance fractures: a multicenter perspective. J. Pediatr. Orthop., 2011, vol. 31, no. 7, pp. 741-744. DOI: 10.1097/BPO.0b013e31822f1b0b.

18.Baindurashvili A.G., Vissarionov S.V., Falinskii A.A., Soloveva K.S. Organizatsiia meditsinskoi pomoshchi detiam s povrezhdeniiami pozvonochnika v Sankt-Peterburge [Organizing medical care for children with injuries of the spine in St. Petersburg]. Ortopediia, Travmatologiia i Vosstanovitelnaia Khirurgiia Detskogo Vozrasta, 2014, vol. 2, no. 4, pp. 8-14. (in Russian) DOI: 10.17816/ PTORS248-14.

Received: 24.01.2019

\section{Information about the authors:}

1.Alexei G. Baindurashvili, M.D., Ph.D., Professor, member of RAS, honored doctor of the Russian Federation, The Turner Scientific and Research Institute for Children's Orthopedics, Saint Petersburg, Russian Federation, Email: turner01@mail.ru

2. Anna V. Zaletina, M.D., Ph.D., The Turner Scientific and Research Institute for Children's Orthopedics, Saint Petersburg, Russian Federation, Email: omoturner@mail.ru

3. Sergei V. Vissarionov, M.D., Ph.D., Professor,

The Turner Scientific and Research Institute for Children's Orthopedics, Saint Petersburg, Russian Federation,

Email: vissarionovs@gmail.com

4. Karina S. Solovyova, M.D., Ph.D.,

The Turner Scientific and Research Institute for Children's Orthopedics, Saint Petersburg, Russian Federation, Email: omoturner@mail.ru 